\title{
THE DYNAMICS OF SMALL TOWNS IN FRANCE
}

\author{
Valérie Jousseaume ${ }^{1}$, Magali Talandier ${ }^{2}$
}

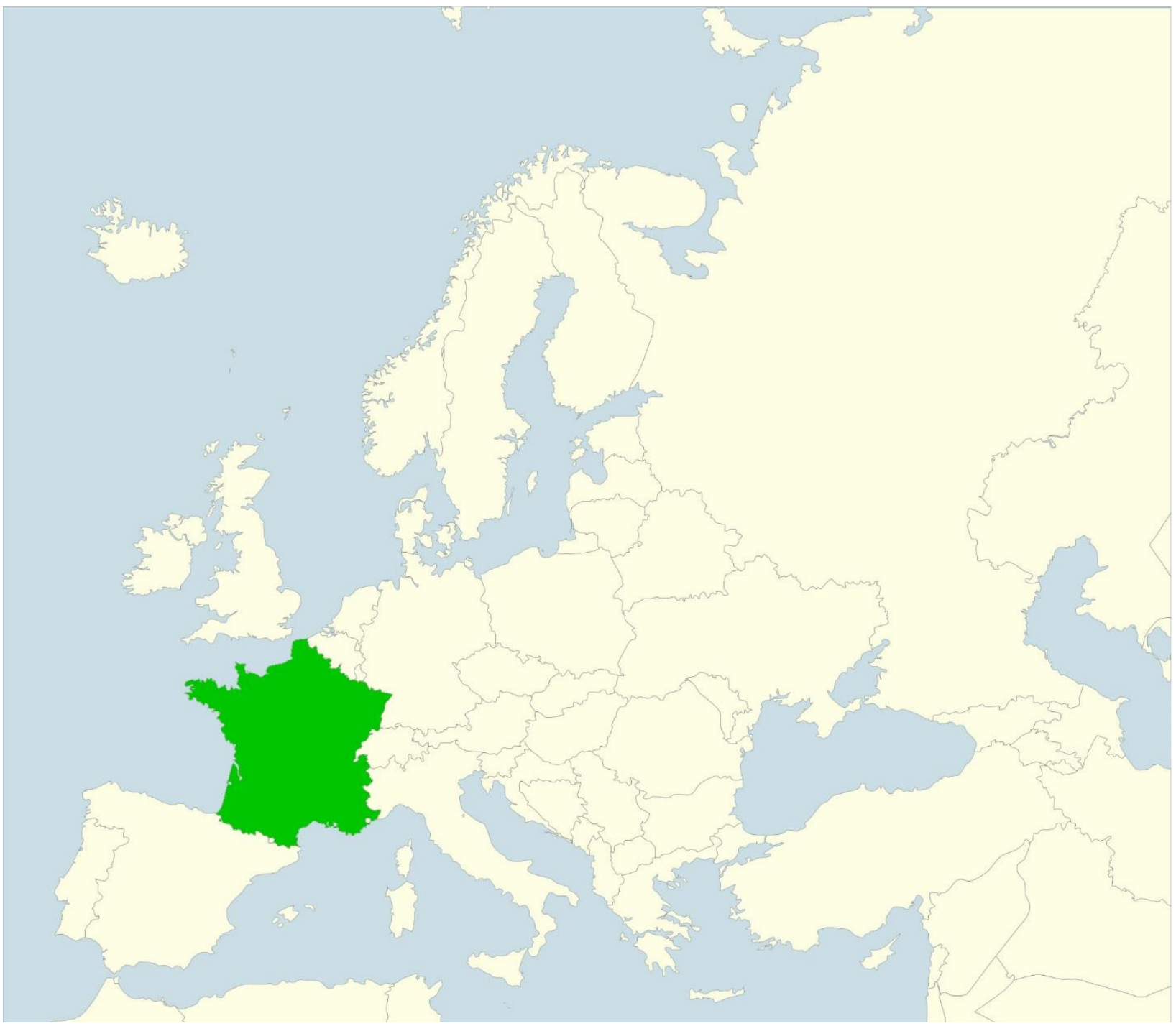

\footnotetext{
${ }^{1}$ Ms Valérie Jousseaume, PhD. University lecturer, University: Institut de Géographie et d'Aménagement, Université de Nantes (Igarun), France, Research team: CNRS - UMR 6590 ESO, Postal address: Igarun, Campus du Tertre BP 81 227, 44312 Nantes cedex 3, France; e-mail: valerie.jousseaume@univ-nantes.fr

2 Magali Talandier, PhD. University lecturer, University of Grenoble-Alpes, France, Research team: CNRS - UMR 5194 PACTE, Postal adress: Institut de Géographie Alpine, 14 bis avenue Marie Reynoard, 38100 Grenoble, France; e-mail: Magali.talandier@univ-grenoble-alpes.fr
} 


\begin{abstract}
This article is based on a renewed, unified functional definition of France's urban hierarchy. Our ranking defines small towns exclusively in terms of their commercial and service functions, not according to size (population or jobs). Accordingly small towns are characterized by their function both in terms of education (presence of a high school), healthcare (a hospital with an operating theatre) and trade (a supermarket with floorspace exceeding 2,500 square metres). The population of small French towns identified using these criteria ranges from 6,200 to 35,500, with 3,500 to 19,000 jobs, depending on their regional context. Large hub-bourgs, defined as places hosting a secondary school, supermarket and nursing home, emerge as the lower limit of the urban world, interfacing with the countryside. In several ways they might count as 'very small towns', with a population ranging from 2,400 to 13,500 , and 1,000 to 4,700 jobs. The article then analyses the population dynamic of small towns in mainland France over the past 50 years. This period has witnessed far-reaching changes: an urban then metropolitan model has gradually taken shape and gathered strength. In recent years this process has gone hand-in-hand with the demographic renewal of rural areas.
\end{abstract}

Keywords: urban hierarchy, urban functions, small town, hub-bourg, demographics

Résumé: Cet article repose sur une définition fonctionnelle renouvelée et unifiée de la hiérarchie urbaine de la France. Dans cette hiérarchie, lesuniquement par leurs fonctions de commerce et de service et non par leur taille (de population ou d'emplois). Ainsi, les petites villes y sont caractérisées par leur fonction à la fois en termes d'éducation (présence d'un lycée), de santé (présence d'un hôpital chirurgical) et de commerces (présence d'un hypermarché de plus de $2500 \mathrm{~m}^{2}$ ) Ainsi identifiées, les petites villes françaises ont une population comprise entre 6200 et 35500 habitants et entre 3500 et 19000 emplois, selon leur contexte régional. Les gros bourgs-centres définis comme le lieu où se juxtaposent un collège, un supermarché et un établissement de convalescence, apparaissent être l'ultime seuil urbain à la charnière avec la ruralité. Ils sont par plusieurs aspects de "très petites villes ". Leur population est comprise entre 2400 et 13500 habitants pour 1000 à 4700 emplois. Cetarticle poursuit par une analyse de ladynamique démographique des petites villes au cours des cinquante dernières années. De profondes mutations ont marqué cette période au cours de laquelle s'est d'abord renforcé un modèle urbain, puis métropolitain accompagné d'un renouveau rural et enfin, un modèle territorial régionalisé.

Mots clés: hiérarchie urbaine, fonctions urbaines, petite ville, bourg-centre, démographie

\title{
1. Introduction
}

Our study of small towns started with a research programme on rural areas of western France (Margetic et al., 2014). It seemed worthwhile to study the role of small towns in the buoyant economy of the countryside in this rural area, densely populated and enjoying strong growth. The first obstacle in our path was how best to identify, harmonize and standardize the base of the urban hierarchy in order to compile a cartographic and statistical database, which would in turn be easier to use for quantitative analysis of small towns.

This obstacle may come as a surprise to our fellows elsewhere in Europe, however the definition of what constitutes a 'town' varies a great deal in Europe, all the more so with regard to small towns (Servillo et al., 2014). In France there is no official, widely accepted definition of what characterizes a 'small town'. At an administrative or judicial level the French state acknowledges the existence of more than 36,000 communes, the seats of municipal authority (their borders coinciding with those of the parishes, which preceded the administrative reforms made by the French Revolution of 1789). Central government never refers to towns, large or small, nor bourgs, nor yet villages. It only admits communes or municipalities, all equal before the law, 
reaching down from Paris intra-muros (population 2.2 million) to $80 \%$ of all communes, each home to fewer than 2,000 souls.

What the National Institute of Statistics and Economic Studies (Insee) defines as 'urban' is ill suited to studying small towns. The oldest definition dates from the mid-19th century, describing an 'urban unit' formed by one or more communes of which the central place has more than 2,000 inhabitants. This definition may have made sense in a pre-industrial context (Talandier et al., 2016), but it is now completely obsolete. In the 1990s, in an effort to remedy this problem, Insee extended the above definition by adding a number of jobs to the population-based criterion. So the Institute now uses 'urban hub' to define a commune with a population exceeding 2,000 (in other words an urban unit) and more than 1,500 jobs. For 1,500 to 5,000 jobs Insee uses the term 'small urban hub'. With 5,000 to 10,000 jobs it ranks as a 'medium-sized urban hub'. Over and above 10,000 jobs it counts as a 'large urban hub'. These thresholds make a poor fit with the definitions used by geographers, for whom a small town corresponds more to a threshold of 10,000 inhabitants, a city having a population of at least 200,000 . So Insee's large urban hubs include almost all types of town, from the smallest to the largest. What Insee defines as small and medium-sized urban hubs, geographers, and the general public for that matter, would be more inclined to see as large rural or peri-urban bourgs, resulting in a certain amount of semantic confusion, exacerbated by the regional variations specific to so large a country. In short France lacks a single, common definition for the idea of a small town.

The aim of this article is therefore to start by presenting a methodology for defining, in a unified fashion, the small towns of mainland France. It then analyses population and employment trends in these small towns, from the 1960s to the present day, adopting a hierarchical perspective comparing small towns to the upper and lower echelons, and a spatial perspective, observing the regional dynamics at work in small towns in France as a whole. The first part describes the theoretical context. The second presents an empirical method for defining small towns. The third part presents our findings, leading into a discussion.

\section{Theoretical contex}

The purpose of this part is to extract a single definition of the small town from the learning accumulated on the issue of the urban framework. By 'urban framework', we refer to the hierarchically ranked set of towns which form a mesh covering a territory. So it includes the idea of a hierarchy, which supposes various levels of quantity, quality and rarity, and relations between these sub-systems (Rochefort, 2002; Batty, 2006).

\subsection{Abundant literature}

Although there is no general theory of geographical space, there is a corpus of theory described in a large number of works on spatial analysis. In the same way the massive work of synthesis by Paul Bairoch (1985), the PhD theses of Denise Pumain (1982) and François Moriconi-Ebrard (1993), and all Walter Christaller (1933) and August Lösch (1954)'s publications on central-place theory afford an essential theoretical perspective, a macroscopic view and long-term study (Berry and Garrison, 1958; Hall, 1995a). Work on this subject has been carried out all over the world (Hall, 1995b; Chen and Partridge, 2013; Dobis et al., 2015). Though of considerable merit, the above works are nevertheless of limited value to our research, given its particular perspective, because they focus on major cities and often disregard lower urban levels. For example the summary by Pumain and Thérèse Saint-Julien (1976) focuses on towns with a population between 20,000 and 80,000. However this approach is much less pertinent for the lower echelons of which the small demographic size varies significantly from one region to the next as a function of regional density (Bergeron and Roncayolo, 1977).

To remedy these shortcomings we have drawn on the many and varied studies of France's regional framework. Very briefly we should point out that in France this work started in the 1950s with a surge in the volume of research into 'zones d'attraction commerciales', or trading catchment areas, carried out in each of the 95 départements of mainland France, using the method established by André Piatier (1956). This commercial perspective produced the first data for objective analysis of the economic organization of territories, serving as the basis for the regional 
action programmes (PAR) launched by central government in 1955. There followed a large number of regionally focused $\mathrm{PhD}$ theses. From the outset this research was closely linked to the state's regional development policies. Coordinated by the Interministerial Delegation for Territorial Development and Regional Attractiveness (Datar) from 1963 onwards, these policies initially targeted large cities, drawing on the work of the geographer Michel Rochefort among others, then turned to medium-sized towns, and finally small towns. This second wave, led by geographers Bernard Kayser and Jean-Paul Laborie, went hand-in-hand with the 'pays', or locality-oriented, policies launched in the early 1970s (Veyret-Verner, 1970; Kayser et al. 1972; Laborie 1979; Lugan, 1983; Genty, 1984). Twenty years later, in 1990, it was again the prospect of reforms requiring closer cooperation between communes, or municipalities, which led to the setting up of a national research network, centring on Kayser and in association with the Ministry of Agriculture, to address the issue of hub-bourgs (Kayser, 1993). At the same time renewed policy-making interest in the pays echelon, in the mid-1990s, fuelled fresh collaboration between Datar and geographers, with a series of conferences, at Nantes in 1995 (Laborie et Renard, 1997), Tours in 2010, then Avignon in 2014, and various articles and theses focusing on small towns (Hilal et al., 1995; Jousseaume, 1996; Oger, 1996; Pasquet, 1999; Edouard, 2002 and 2008; Roques, 2009).

\subsection{Theoretical description of small French towns}

On the basis of this literature and our own research we have tried to produce a concise description of the small town, in the context of France's overall urban hierarchy.

The pre-industrial agrarian macro-economic environment resulted in a Christallerian organization of space, founded on ranking of market places and administrative centres. In this old-world context, towns - which were small compared to present conditions - were the place where the added value derived from working the land accrued, primarily in two ways: through rent on land, and trade in farm produce and non-food goods (Jousseaume, 1997). The small town was the level at which the lower echelons of the middle classes lived and socialized. They comprised mainly landowners living off their rents. This too was the site of agricultural fairs, and big weekly markets where one could purchase clothes, leather goods, tin pans and tools. To these core functions were added welfare (alms house, hospital and maternity home) and educational functions, over and above primary schools (secondary school, agricultural training), often linked to religious institutions. In farming areas, subject to limited individual mobility, small towns were service centres, feeding on the agricultural activity of the environs with which they were on close terms. These few attributes (lower middle class, fair, market, hospital, secondary school) are sure indicators of this elementary urban level during the period leading up to the mid-20th century in western France. The catchment area of such centres had a radius of about 15 kilometres (Jousseaume, 1996).

In the context of mid-20th century Fordist industry, this urban system was completely called into question, because its basic economic function (land rent, trade in farm produce and non-food goods) became obsolete, due to the effects of industrial development, the growth of food supply chains, the advent of mass retailing and consumer mobility. The object that may be qualified as a "small-town, pre-industrial centre of trade" disappeared as a system, even if its defining structures remain, much as the shell of some dead mollusc.

The new industrial economic system, which spread downwards from the top of the hierarchy, reused these structures. But it also fostered a scale effect, in other words a demographic growth rate proportional to the size of the town (Madoré, 2002). As a result small, old towns split into two groups, in blunt terms winners and losers. The successful ones had the largest structures and went on serving as functional centres in the Fordist industrial economy, attracting factories and jobs. As such P. Dubosq (1977) defined the small town as the place where added value from workers' labour was collected. The arrival of mass distribution, the Fordist version of retailing (which is highly developed in France), confirmed the commercial functions of these towns. This process has also consolidated, or even extended their catchment area over the surrounding 'pays'. We shall assimilate this system with the functional small town.

The losers were former market towns, very probably smaller than their more successful counterparts. Certainly their industrial function was not as well consolidated. Their role as a hub 
was more a legacy of the past, which may have given such localities an advantageous scale effect in trading terms, but it could be undermined by neighbouring localities, for example in the context of peri-urban development. The administrative legacy of the main town in a canton [a sub-division of the larger département] also represented a substantial advantage, with the presence of a secondary school, gendarmerie or police station, and tax office. We shall refer to this level as the hub-bourg. Such towns concentrate various food shops and domestic services, but their catchment area is shrinking, only reaching into adjoining localities.

In the post-Fordist context of the late-20th century, the system's economy is still rooted in the production and consumption of goods, but business services such as research, information technology, finance, innovation and marketing have increasingly superseded industry as the driving force. There is a clear correlation between size and the ability to adapt to change, benefiting from the initial advantages of innovation (Pumain et al., 2006). The timing of the transition between crisis in the industrial apparatus and growth of business services seems to be a good indicator of a town's position in the urban hierarchy, onset coming earlier in the largest cities. This shift brings about powerful growth in employment, particularly in business services or upper-echelon metropolitan positions, with substantial growth in the outer perimeter of these metropolises (Julien, 2002). In contrast small towns remain locked in a Fordist industrial model, adaptation being forced upon them by the pressure of international competition. Between the two, after rapid integration in the Fordist industrial organization in the past, medium-sized towns have recently 'disconnected' from the echelon above. They have struggled to achieve the post-industrial metamorphosis which has occurred in cities, while no longer offering specific assets for industrial production (Santamaria, 1999; Zuliani, 2002). Over the past 30 years they have been left behind in terms of growth in jobs and population. In western France the picture is less clear cut due to the proximity of several medium-sized coastal towns which have found fresh momentum as seaside resorts.

On the basis of the preceding functional definition and Jousseaume's field observations (1997, 2000 and 2013), the present article now proposes to identify relevant indicators for the levels in the current urban hierarchy, placing the emphasis on small towns.

\section{Methodology for identifying functional small towns}

Drawing on the many variables cited in the literature or observed in the field we have sought to extract the most relevant indicators for each urban level. The operational focus of our work meant that we chose a limited number of readily accessible, homogeneous indicators. For this purpose we concentrated on variables available for French communes, the country's smallest administrative unit. We opted to use the Base Permanente des Équipements, or permanent facilities database, collated by the National Institute of Statistics and Economic Studies (Insee), an online inventory, updated annually, of business and services in each commune.

It is important to bear in mind that the selected indicators do not explain the level they describe; they are simply markers of that level. Nor do these indicators have any long-term value; they evolve with the macroeconomic system. There would consequently be no point in making them permanent. Similarly, in defining a settlement as a small town we have not sought to determine whether or not it is located in a suburban area; we have merely noted the latter status after the fact.

\subsection{Facilities more relevant as variables than population or jobs}

Attempts to define urban bodies usually start from their demographic weight. Such data is easily accessible, but extremely difficult to use for small towns, where population density and municipal boundaries, and hence the structure of settlement, influence both the volume of people and the facilities in a commune, the basic division used in censuses (Talandier and Jousseaume, 2013). Clearly a town with a population of 8,000 in the Paris suburb does not play the same central role as a settlement of equivalent size in the sparsely populated highlands of central France.

Similarly the 'number of jobs at a single workplace' variable used by Insee to define 'urban hubs' since 1996 might at first sight seem relevant for defining a functional urban hierarchy. However, in our approach we set aside this indicator too, having decided to compare a posteriori our 
hierarchy, based on selected functional criteria, with population or jobs, rather than integrating these variables a priori as defining factors.

\subsection{Facilities indicating urban functions}

Geographical literature cites three main organizing functions: retail trading, healthcare and education. We have disregarded the administrative status of urban units, sometimes a throwback to the early 19th century (and the administrative reforms of the French Revolution and Napoleonic period), rather than reflecting the way they work at present. Starting from a broader selection of variables expressing these variables in the Insee database for 2010 , we have sought to reduce the number of indicators as much as possible, without losing the essential features of each urban level. Proceeding step-by-step we have retained a combination of facilities that is as elementary as possible, while exerting the greatest structural influence at the relevant level in the hierarchy.

Our ranking identifies six levels.

- The hub-village (level 1) is a centre of local trading defined by the presence of a baker's, grocer's or small supermarket.

- The hub-bourg (level 2) is a centre of trading and consumer services, with a supermarket, an indicator of its status as a commercial hub, or a secondary school or nursing home, both of which are indicators of its status as a service hub. Hub-bourgs are either former market towns or peri-urban municipalities which have taken on new hub functions.

- The large hub-bourg (level 3) differs by the simultaneous presence of a nursing home (often a former hospital that has been downgraded by healthcare reforms), a secondary school and a supermarket. Such places are former small towns, dating from before the industrial revolution, which declined in importance during the 20th century, or incomplete small towns, due to the proximity of one or more large towns.

- The small town (level 4) may be characterized by the simultaneous presence of a large supermarket (retail space exceeding 2,500 square metres) with a large retail trading park with specialist shops (mass distribution and consumer equipment, in particular garments), a high school (pupils aged 15 to 18) with a general or technological curriculum, and a hospital, itself correlated with the presence of specialist medical practitioners. We have restricted the indicators to either a short-stay hospital or maternity home, a large supermarket or a high school.

- The medium-sized town (level 5) may be characterized by the presence of a branch of a university, more than eight furniture shops, a maternity hospital or emergency ward.

- The capacity for economic innovation of cities (level 6) is strongly correlated with the presence of research. We have consequently chosen the presence of a university's headquarters as the indicator of this level. This might surprise our fellows in other European countries, where the location of universities sometimes dates back to the Middle Ages and has little to do with the contemporary urban hierarchy. However this is not the case in France where all the universities were shut down during the Revolution, then re-established in major towns under close state supervision.

\subsection{Identifying small French towns}

On the basis of this definition we obtained Figure 1, which enables us to visualize France's functional urban framework in 2010 . It reveals a country covered by a dense mesh, with abundant facilities thanks to its bourgs and small towns reaching out into the countryside (Talandier and Jousseaume, 2013). The six hierarchical levels defined above yield the following breakdown: 45 university cities, 110 medium-sized towns, 251 small towns, 769 large hub-bourgs, 1,915 hubbourgs and 8,148 hub-villages. Our ranking omits about 26,000 municipalities in France, because they have none of the facilities corresponding to the central role we have defined. 


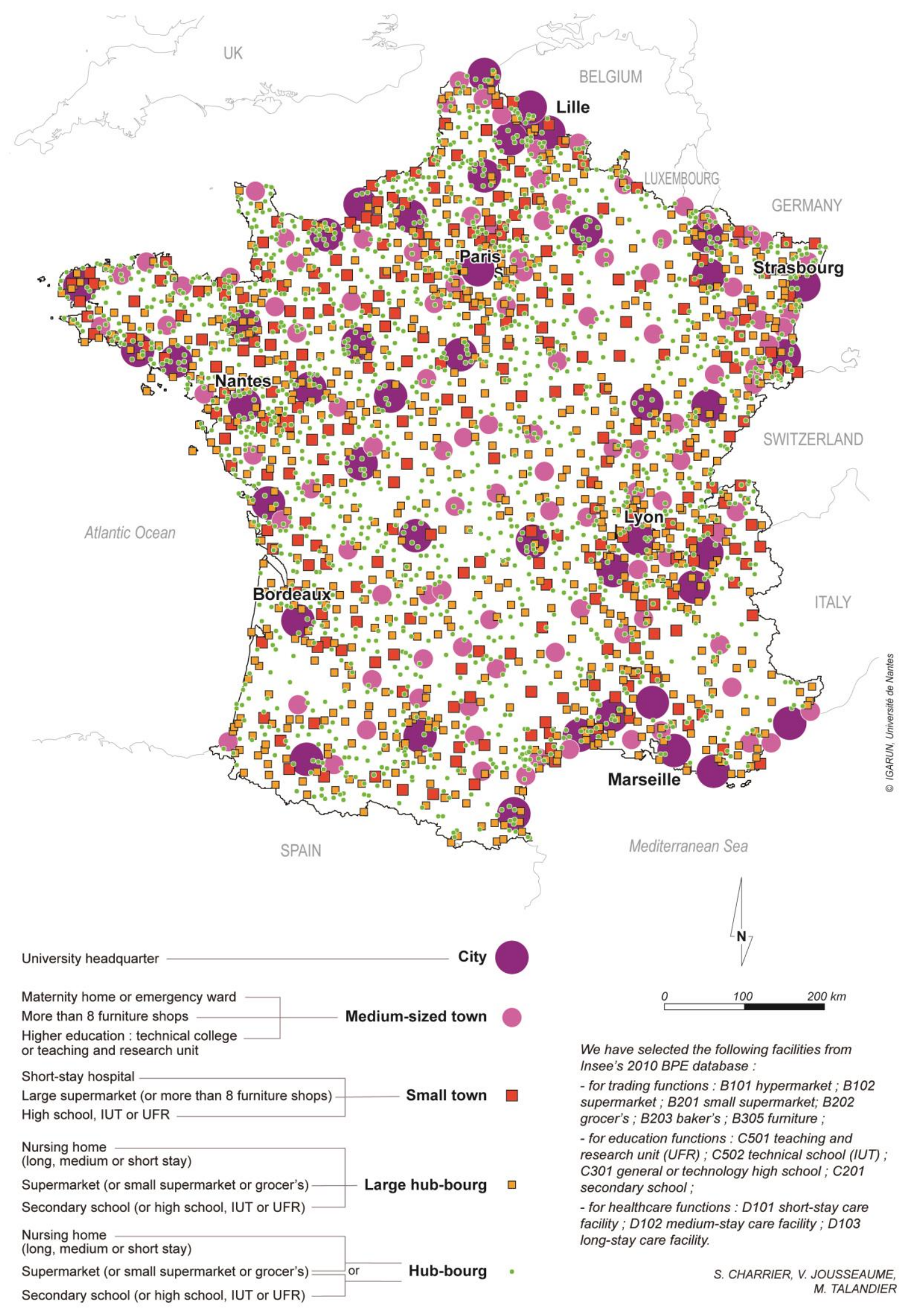

Fig 1. France's urban framework in 2010. Source: Talandier and Jousseaume, after Insee, BPE 2010

Predictably, the higher up the urban hierarchy one looks, the more the population increases, as does density and the number of jobs. According to our method, in $80 \%$ of cities the population ranges from 120,000 to 1 million; from 20,000 to 100,000 in medium-sized towns; from 6,200 to 35,500 (in 2012) in small towns; 2,400 to 13,500 in large hub-bourgs; 1,100 to 3,300 in hub- 
bourgs; and finally from 280 to 1,850 in hub-villages (Figure 2). The population values found in France are of the same order of magnitude as in the four lower echelons of the urban hierarchy defined by Christaller (1933; Dickinson, 1967) as the basis for the ranking in the mid-20th century Germany: Marktort, 1,000 inhabitants; Amtsort, 2,000; Kreisstadt, 4,000; Bezirkstadt, 10,000. It should be pointed out that, with 118 inhabitants per square kilometre, the current average population density in France is half that found in Germany.

The large disparities between the upper and lower boundaries of each level are partly due to the regional context. The most populous functional small towns, with a population of about 70,000 , are located in the urban areas of Geneva, in Switzerland, Lille, in northern France or on the outskirts of Paris (Aguilera and Mignot, 2004). At the other end of the scale the least populous small towns have a population of about 4,500 . They are located in sparsely populated rural areas, in particular medium-altitude highlands. They undoubtedly serve as towns for local people, both as hubs for shopping, schools and healthcare. This example holds true for all the urban echelons.

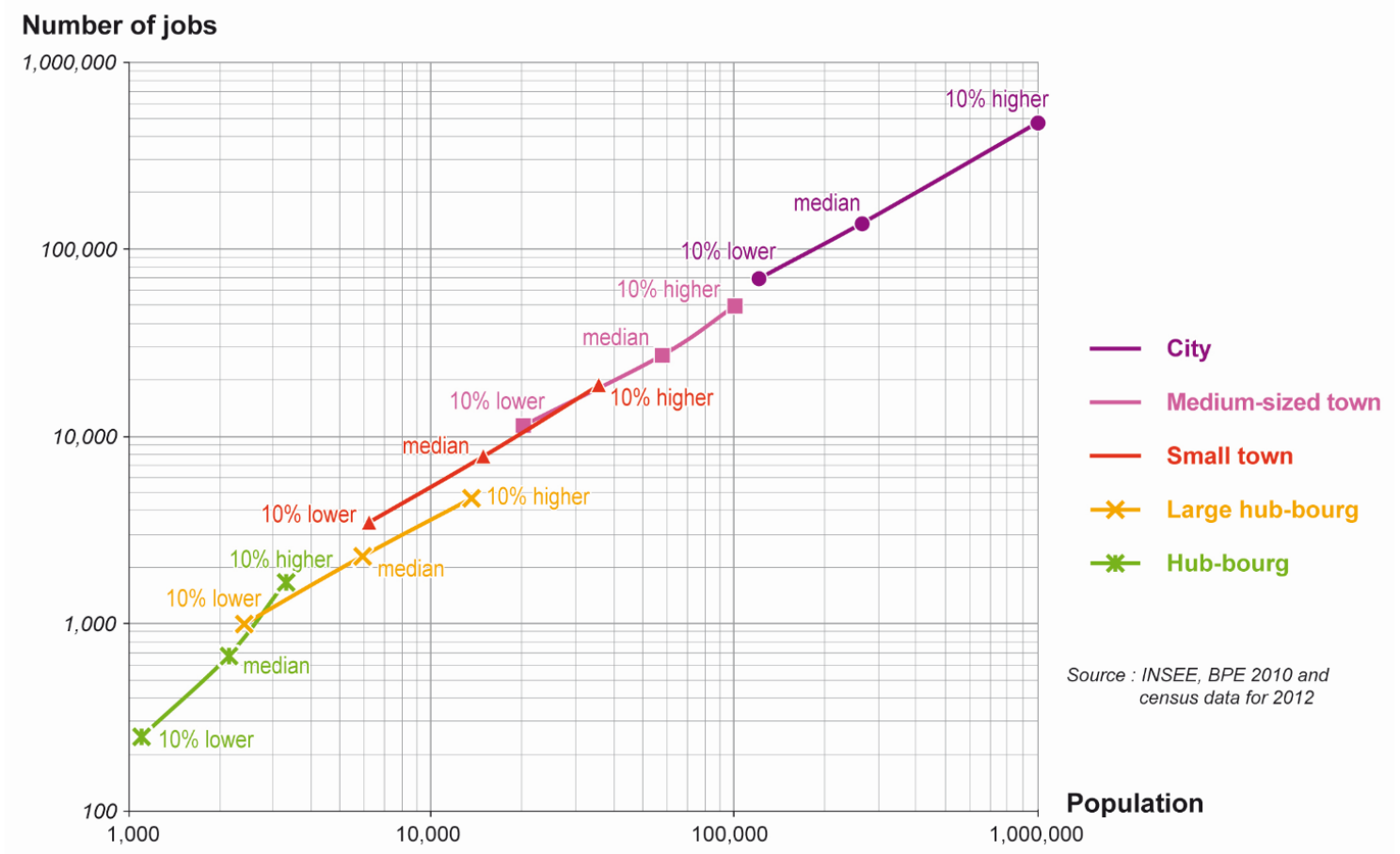

Fig 2. Population and jobs in 2012. Source: Talandier and Jousseaume, after Insee, BPE 2010 and 2012 census

Building on this definition, we may examine the dynamics of small towns in France.

\section{Results and discussion}

Building on this work identifying the levels of France's urban hierarchy we shall now sketch out the key demographic and economic changes these small towns have undergone, and their part in the nation's overall territorial dynamics, from 1968 to the present day. In view of our results, it is important to emphasize immediately that small towns (level 4) may be supplemented by large hub-bourgs (level 3), which, as we will see in the following exposition, behave like a 'a very small town' and seem to constitute the real threshold between the urban and the rural.

\subsection{Urban hierarchy and demographic dynamic: reversal of trends and homogenization}

France has witnessed a complete reversal of its demographic growth trends. In 1968 the demographic growth rate was correlated to the urban hierarchy: the higher up the urban hierarchy one moved the faster the population was growing. By 2012 this trend had been completely reversed (Figure 3). 
Up to the national census of 1975 the annual growth rate in all the urban echelons, from cities down to large hub-bourgs, ranged from $1.15 \%$ to $1.25 \%$. Meanwhile hub-villages and communes with no facilities declined.

At the end of the 1970s growth in towns of all sizes slumped significantly. The year 1968 marked the point when the population of mainland France was most densely concentrated in spatial terms (Talandier et al., 2016). Peri-urban development started in the 1970s, with the population spreading out in space, initially to the outskirts of towns, more recently to more isolated rural areas. This back and forth movement is not specific to France (Monkkonen, 1990; Dobis et al., 2015). Rural rebirth (Kayser, 1990) has affected all western countries, but it has been particularly dynamic in France. People have moved from the Netherlands and the UK to settle in the countryside alongside French nationals, particularly from the 1990s to the mid-2000s (Cognard, 2011).

Rural communes which had been in demographic decline up to the end of the 1970s, started registering population growth, which speeded up towards the turn of the century, exceeding $1 \%$ a year.

In recent years (2007-12) the growth rate has slackened again, without fundamentally altering the trend towards urban exodus.

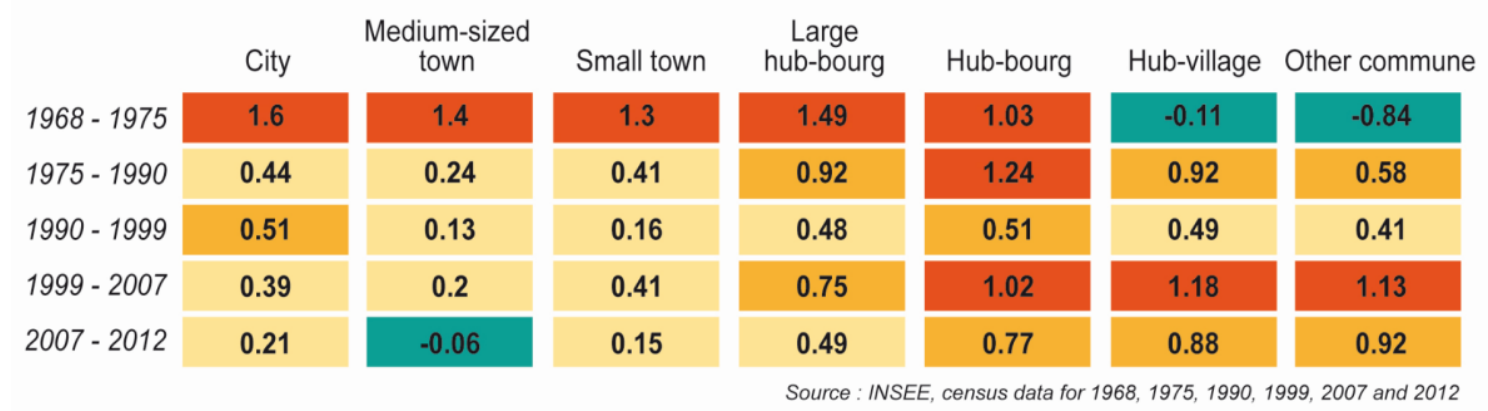

Fig 3. Average annual population growth rate from 1968 to 2012. Source: Insee, census data for 1968, 1975, 1982, 1990, 1999, 2007 and 2012

This slow process of spatial redistribution is based on a reversal of the forces driving demographic growth (Figure 4). Before the turning point of the 1970s the countryside acted as a reservoir of population feeding rural exodus towards urban centres. Afterwards the countryside started becoming attractive. Rural renewal is partly due to urban sprawl, but it is also driven by amenity migration into the country (Talandier, 2012). On the other hand the migratory flow which sustained urban growth has dried up. Since the 1975 census the migratory balance of cities and mediumsized towns has been negative. Their growth has been almost exclusively due to the natural balance (births minus deaths). It should be borne in mind that unlike most other European countries the natural balance (births minus deaths) in France displays a healthy surplus, which currently amounts to four times the migratory balance at a national level. Over the past decade the birth rate in France has steadied at two children per woman. The natural and migratory dynamic of small towns is similar to that of their larger neighbours. They are smaller, closer to the countryside and less metropolitan. They have avoided a completely negative migratory balance, but suffer from a less favourable natural balance than larger urban centres. Large hubbourgs differ from the S-shaped trajectory (see Figure 4) of cities, displaying a more rural pattern. They have not suffered from 'urban' exodus: for a while they attracted country people at a time of rural exodus; then, with the shift in trends, they started attracting townspeople leaving the upper echelons of the urban hierarchy. Although the natural and migratory balance has improved in rural areas, the natural balance has dropped dramatically in large hub-bourgs. They still seem to be attractive as central places, but probably for older people, thanks to the large range of nearby services on offer there. 


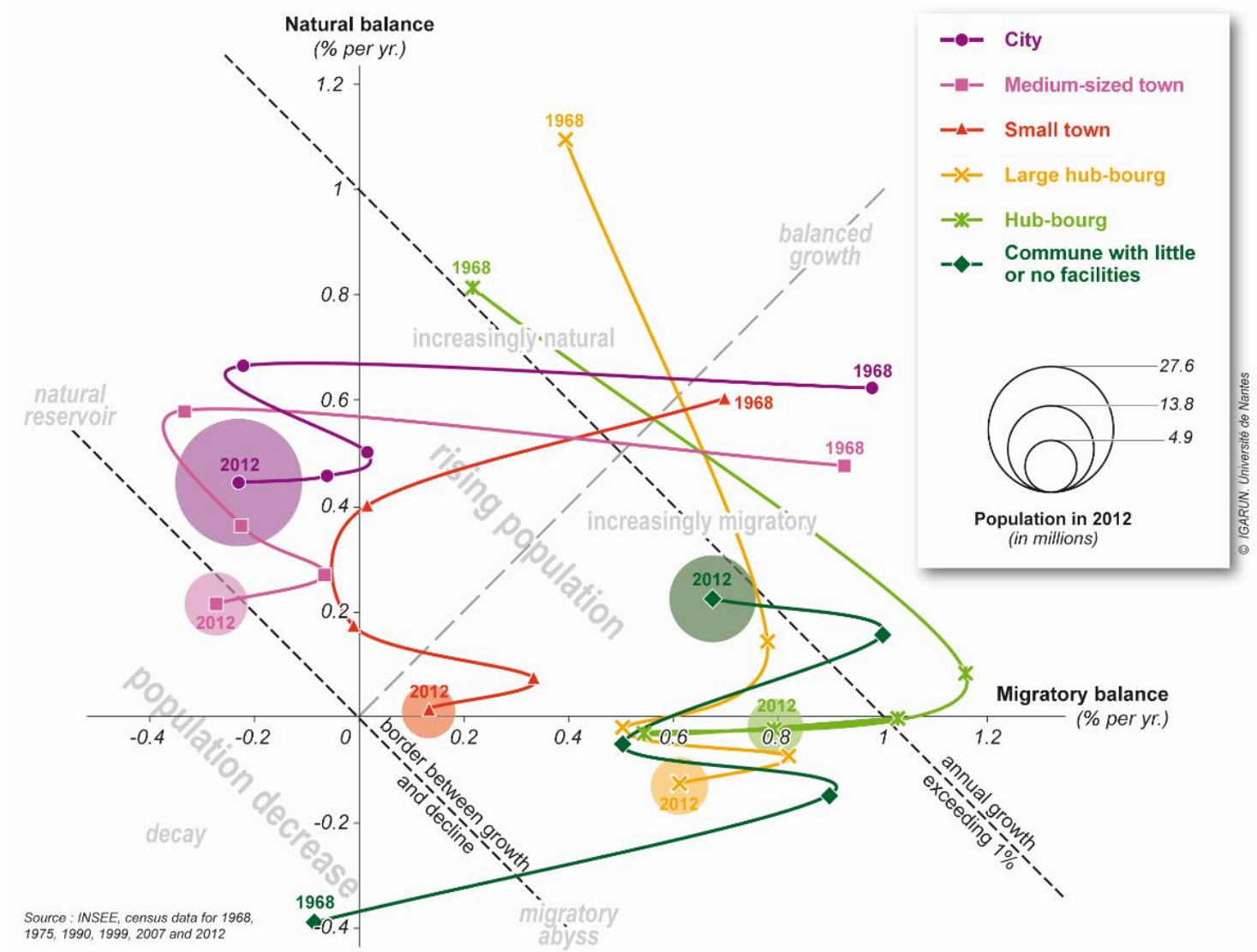

Fig 4. Natural and migratory balance from 1968 to 2012. Source: Insee, census data for 1968, 1975, 1982, 1990, 1999, 2007 and 2012

\subsection{Urban hierarchy and productive dynamic}

In 2012 the various levels in the urban hierarchy may be distinguished by the concentration of jobs: $43.5 \%$ of the population of mainland France lives in a city; $52.4 \%$ of all jobs are located in cities. Medium-sized towns represent $10.7 \%$ of the population, with $13.2 \%$ of jobs; small towns $7.7 \%$ of the population with $8.9 \%$ of jobs. On the other hand hub-bourgs accommodate $5.5 \%$ of the population with only $4.8 \%$ of jobs. The remaining communes, with little or no facilities, are largely residential spaces, home to almost $23.7 \%$ of the population, but only $12.3 \%$ of jobs.

The current job dynamic does not really follow the same pattern as the urban hierarchy. Admittedly between 1999 and 2007, at a time of powerful economic growth, Figures 3 and 5 show an increase in production in all the urbanized levels, down to hub-bourgs often located on the perimeter of an urban area. The number of jobs increased (by between $1.23 \%$ and $1.86 \%$ annually) more steeply than the rise in population. In contrast a residential dynamic concerned the most rural communes with the least facilities. From this point in time the rate of job creation was highest in hub-bourgs.

In 2007-12 the trend went into reverse. Impacted by the crisis of 2008, job creation suddenly stalled, except in rural communes with little or no facilities, but located on the perimeter of an urban area. Here, remarkably, the number of jobs rose by between $0.46 \%$ and $1.2 \%$ a year. These localities seem somehow to have been crisis-proof. The largely residential economy, also fuelled by tourism, was less affected by the crisis which above all impacted heavily industrial sectors, subject to international competition, and through a structural effect, the territories where such firms were located, as was the case with medium-sized and some small towns. So, over the last period, the number of jobs contracted in medium-sized towns, and stagnated in small towns. Occupying the middle ground hub-bourgs saw slight growth in jobs, up by between $0.2 \%$ and $0.3 \%$ a year. Lastly, thanks to a more knowledge-based, less industrial metropolitan economy, France's cities weathered the crisis rather better (with annual job creation at $0.37 \%$ ) (Davezies, 2012; Fujila, 2013). 


\begin{tabular}{|c|c|c|}
\hline & \multicolumn{2}{|c|}{ Job trends } \\
\hline & $\begin{array}{l}1999 \text { - } 2007 \\
(\% \text { per year) }\end{array}$ & $\begin{array}{l}2007 \text { - } 2012 \\
\text { (\% per year) }\end{array}$ \\
\hline City & 1.66 & 0.37 \\
\hline Medium-sized town & 1.23 & -0.23 \\
\hline Small town & 1.45 & -0.04 \\
\hline Large hub-bourg & 1.89 & 0.29 \\
\hline Hub-bourg & 1.86 & 0.21 \\
\hline Hub-village & 1.34 & 1.56 \\
\hline Other commune & -0.28 & 0.46 \\
\hline
\end{tabular}

Source : INSEE, census data for 1999, 2007 and 2012

Fig 5. Annual rate of job creation in 1999 - 2012. Source: Insee, 1999, 2007 and 2012 census data

\subsection{Population dynamic in France shifting from a hierarchical to a regional pattern}

After observing the situation of small French towns in relation to the whole urban hierarchy, we shall now turn to the geography of small towns on French territory. We have opted to divide the population dynamic into five periods (industrial phase or model, 1968-75; industrial decline or post-industrial model, 1975-90; start of metropolitan development or cognitive model, 1990-99; finally a pre-crisis metropolitan model, 1999-2007, and a crisis metropolitan model, 2007-12 (Bell, 1976; Mellander et al., 2011; Berry et Wheeler, 2005). There are three maps for each period. These maps serve to distinguish the population dynamic of small towns and large hub-bourgs, on the one hand, and to compare this dynamic with cities and medium-sized towns, on the other (levels 5 and 6 in our hierarchy), but also with the countryside (including communes ranked on levels 1 and 2, and those outside our hierarchy). This representation enables us to single out levels 3 and 4 (respectively large hub-bourgs and small towns) in the population dynamics of these territories.

In 1968-75 (Figure 6a), at the tail end of western Europe's post-war boom years (1945-75), all cities and medium-sized towns were enjoying powerful growth, except the old coal mining areas of northern and eastern France, already hit by industrial difficulties. Small towns as a whole were also enjoying sustained growth, playing an active part in the dynamic consolidating the urban model. However this was not the case for large hub-bourgs, which were more sensitive to the regional context. Some large hub-bourgs suffered decline in the south-west quarter of France, with its sparse urban network and struggling rural economy, also in the far north-eastern corner, where long-standing heavy industry was running into difficulties. During this period, there was a positive correlation between the population dynamic and urban hierarchy: the higher up the urban hierarchy one moved, the more variations in population were positive. Small towns fitted perfectly into the prevailing urban dynamic. 

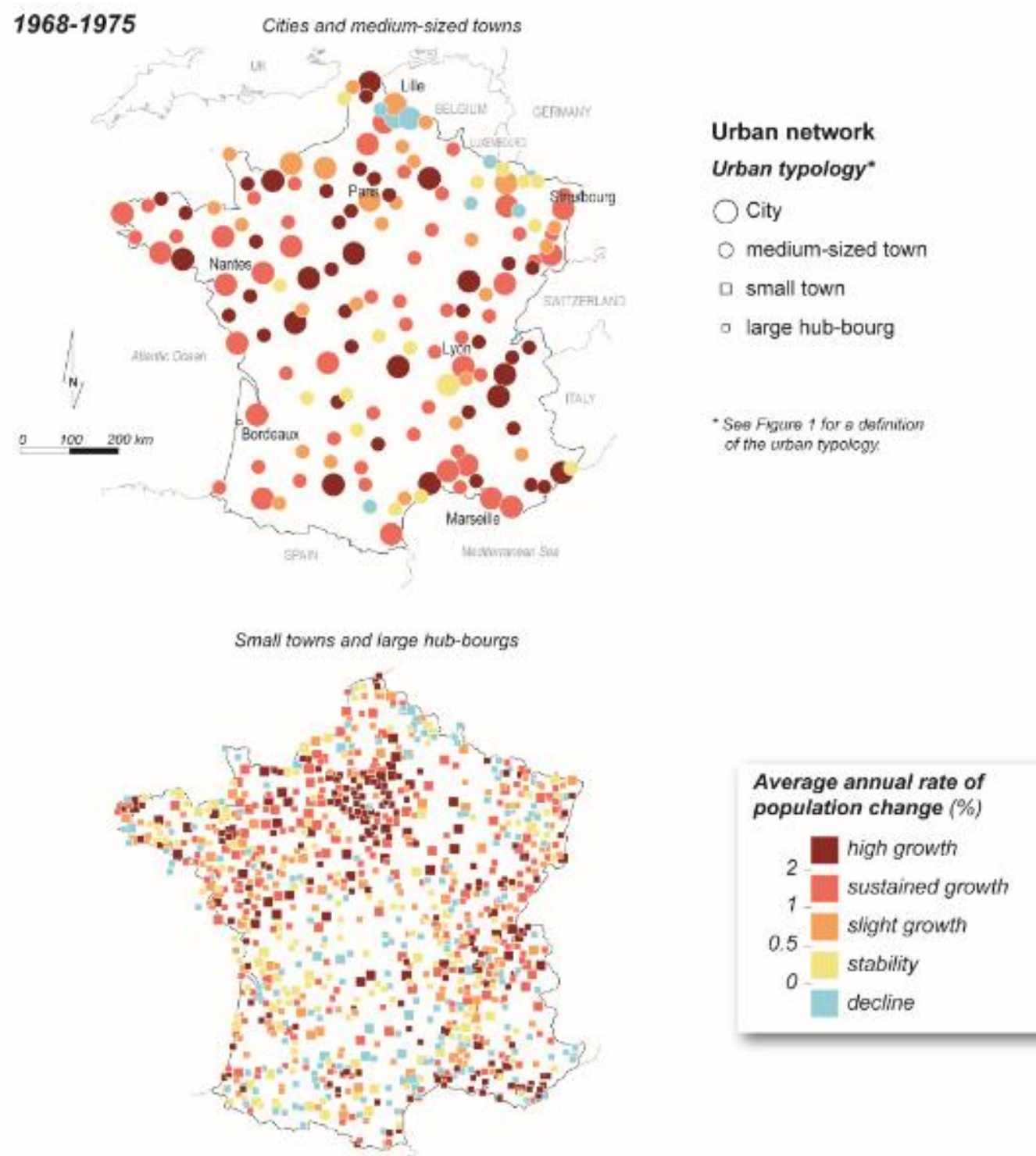

Hub-bourgs and other communes

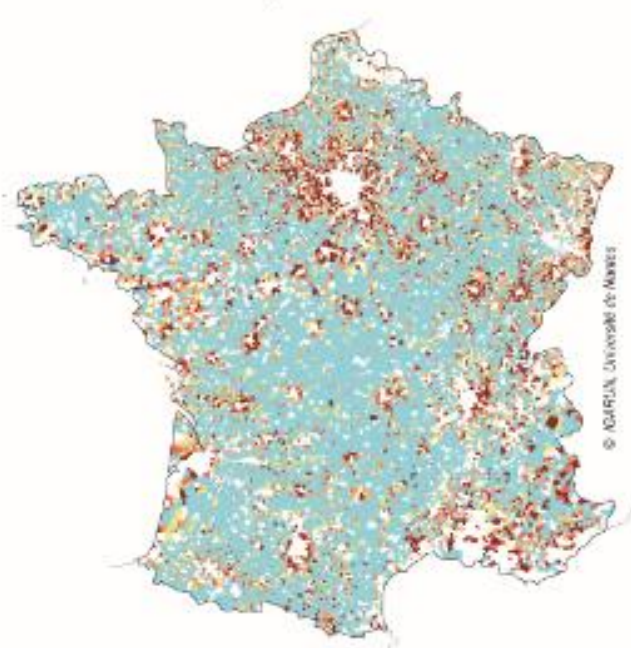

\section{Rural space}

Communes with litte or no facilities

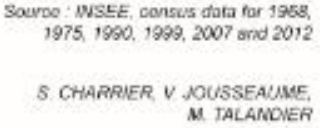

Fig 6a. Urban network and annual rate of population change. Source: Talandier and Jousseaume, after Insee, census data for 1968 - 1975 
1975-1990

Cities and medium-sized towns

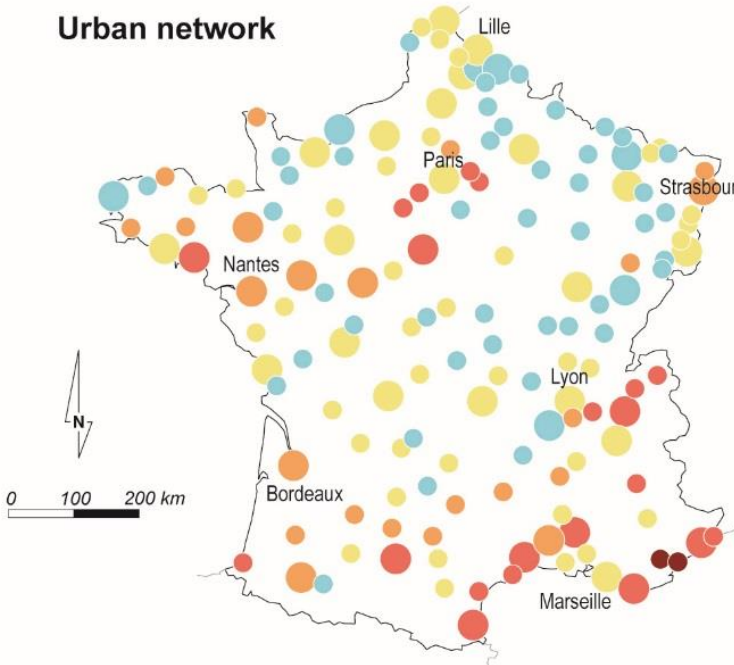

Small towns and large hub-bourgs

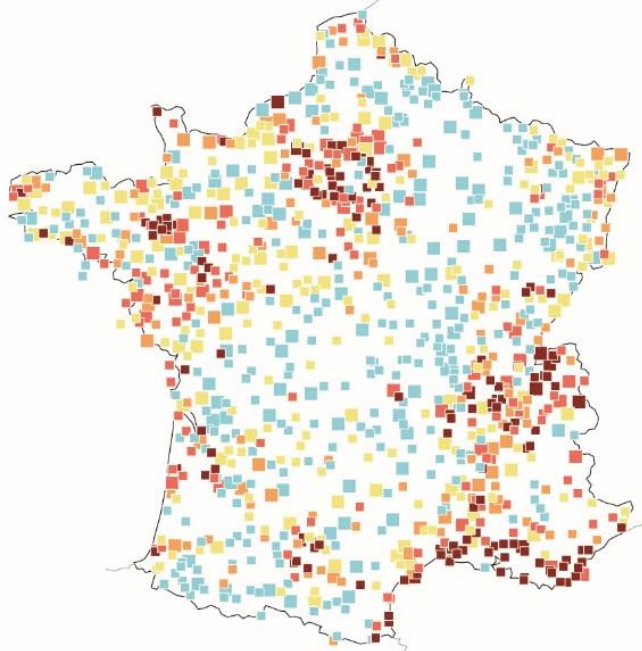

Hub-bourgs and other communes

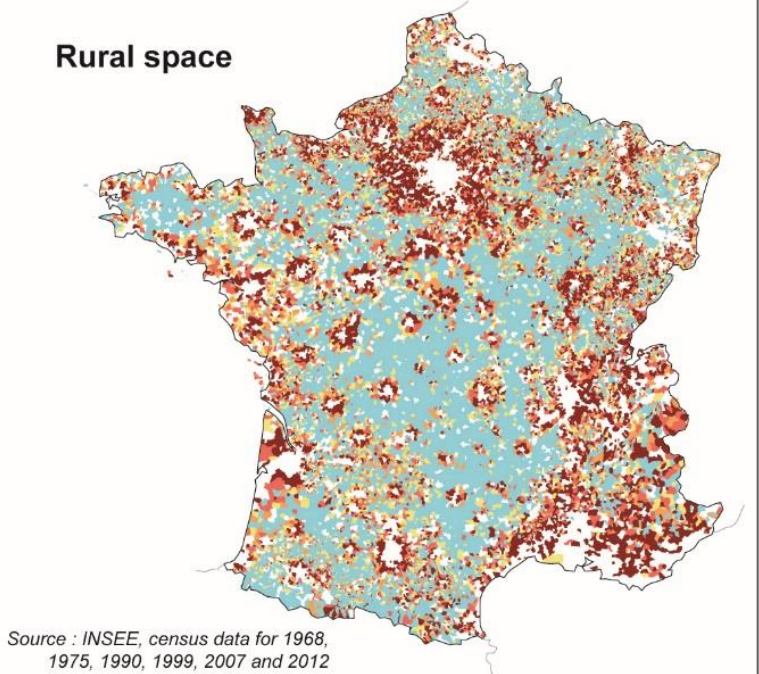

1990-1999

Cities and medium-sized towns

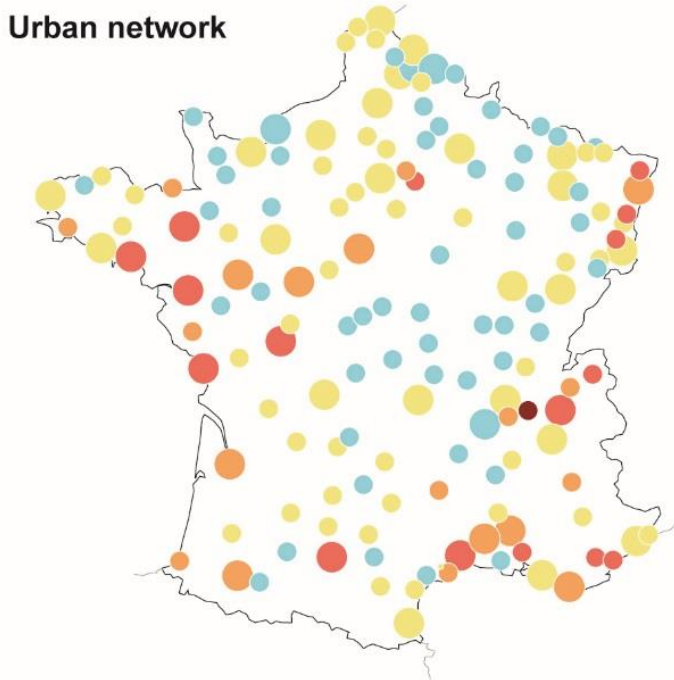

Small towns and large hub-bourgs

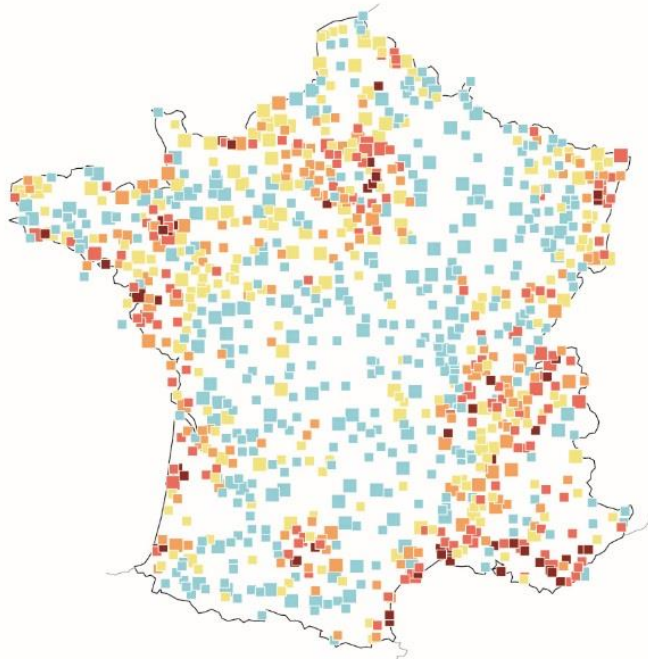

Hub-bourgs and other communes

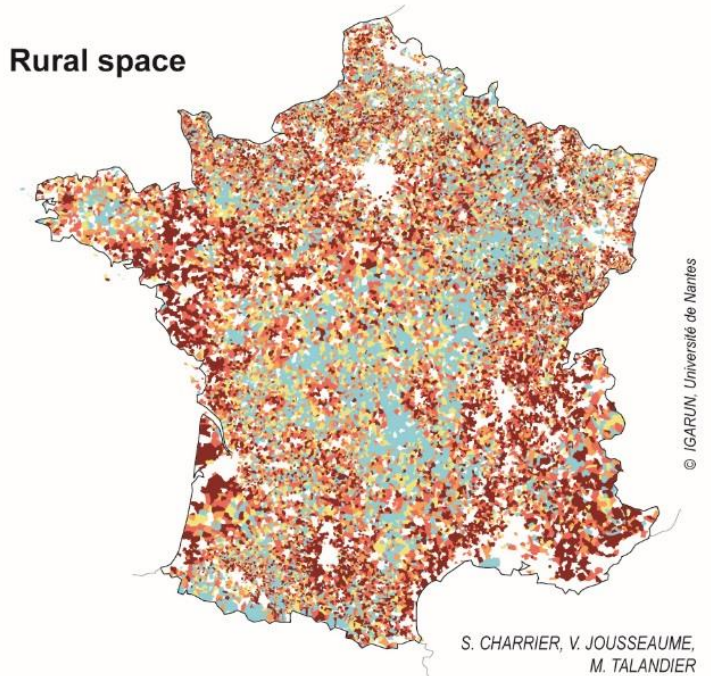

Fig 6b, 6c. Urban network and annual rate of population change. Source: Talandier and Jousseaume, after Insee, census data for 1975 - 1990 and 1990 - 1999 
1999-2007

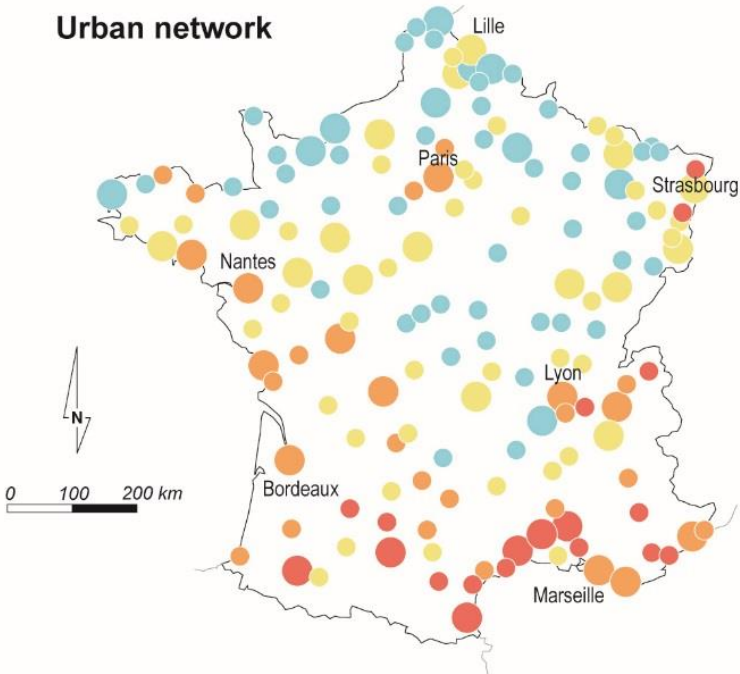

Small towns and large hub-bourgs

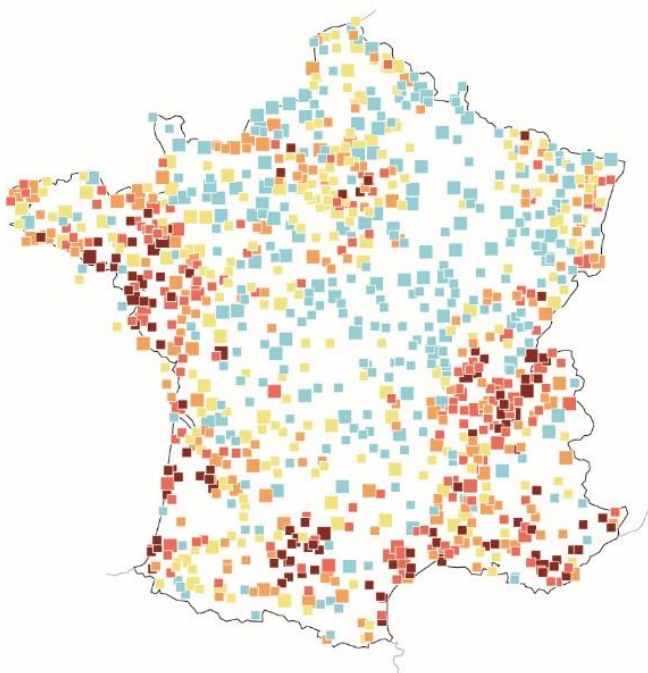

Hub-bourgs and other communes

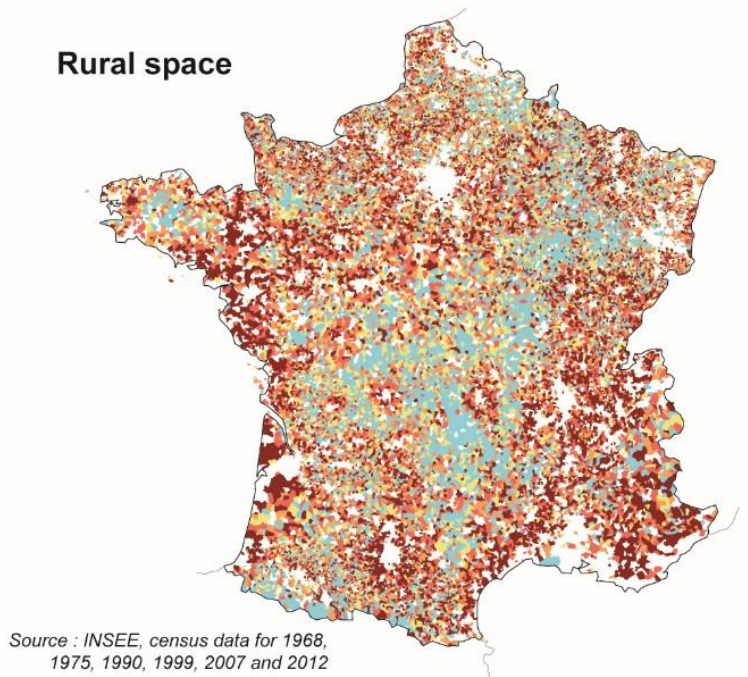

2007-2012 Cities and medium-sized towns

Urban network

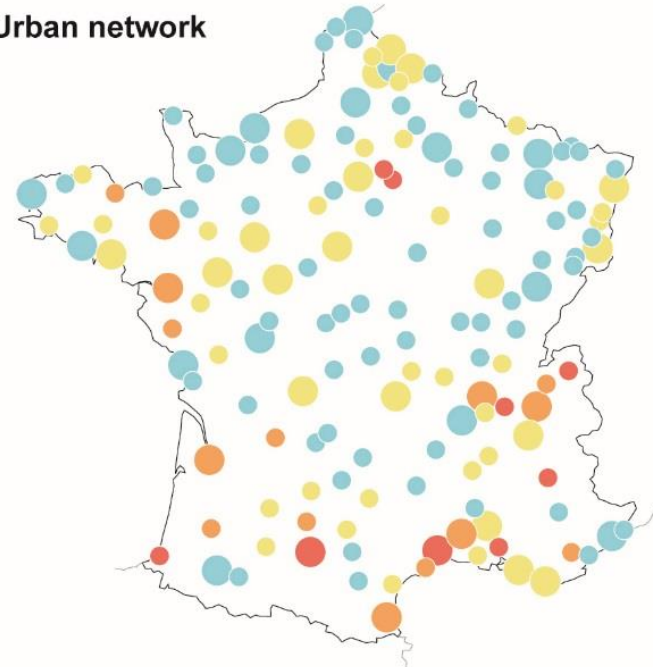

Small towns and large hub-bourgs

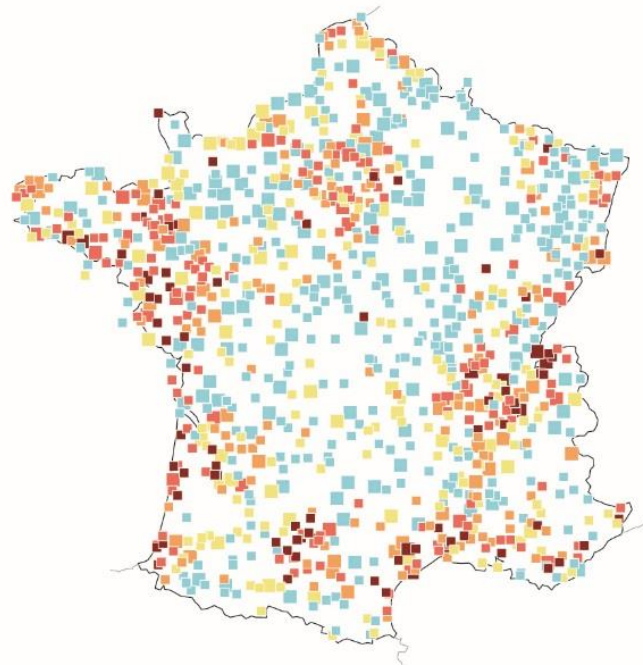

Hub-bourgs and other communes

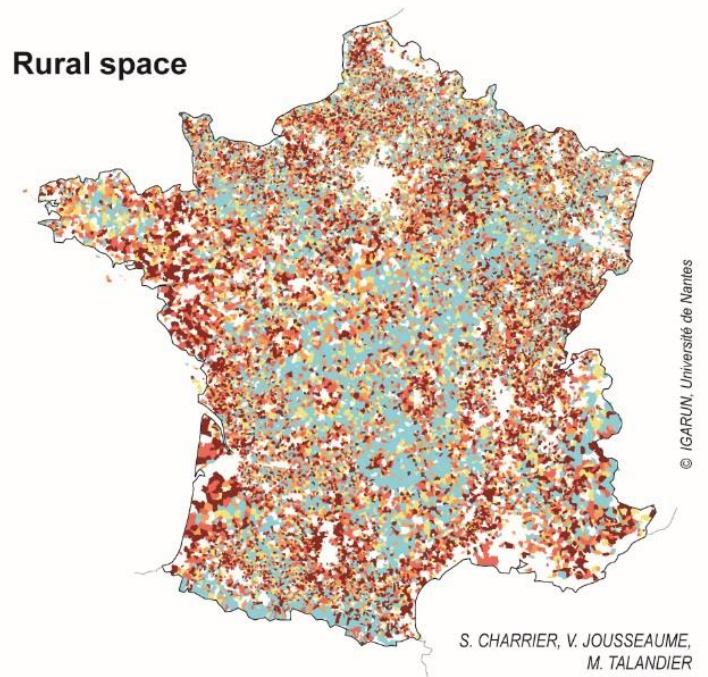

Fig 6d, 6e. Urban network and annual rate of population change. Source: Talandier and Jousseaume, after Insee, census data for 1999 - 2007 and 2007 - 2012 
The following period, 1975-90 (Figure 6b), saw the transition from a crisis-ridden Fordist economy to a new, metropolitan economy, increasingly service and knowledge-based, which was gradually taking shape. With the industrial downturn urban growth suddenly slowed, while at the same time peri-urban expansion took off, made possible by widespread access to motor vehicles from the 1970s onwards. The population dynamic of the French countryside diverged, taking two separate courses: near to urban centres it enjoyed growth; elsewhere by and large it declined. In regions with dynamic cities - the Paris area, western France, and around Toulouse in the south, the south-east, along the Rhône valley and Mediterranean coast - small towns and large hubbourgs benefited from this peri-urban dynamic. Further away from the main cities or in crisisridden north-eastern France, small towns and large hub-bourgs were hit by population decline.

From 1990 onwards (Figures 6c, 6d and 6e) population growth in towns gradually slackened. From 2007 onwards medium-sized towns actually shrank, apparently lacking both the metropolitan assets of a city and the amenities of the countryside. The population dynamic of small towns and large hub-bourgs steadied. In all France's rural areas, except the bleak uplands of the Massif Central (Pistre, 2013), the population once again increased. Almost all of rural France registered a positive migratory balance. In areas where the population continued to shrink it was due to a negative natural balance. The crises of 2008 and 2011 slowed the rate of migratory movement inside France (Figure 3), without altering the spatial distribution of the population dynamic governed by a regional rationale (Figure 6e) (Baccaïni, 2007; Talandier, 2013).

The rising population of cities was mainly due to a high natural balance and new drawing power for qualified workers, students and other socio-professional profiles who contributed to the dynamic of metropolitan development. All over France, much as elsewhere in Europe, large metropolitan areas constituted the driving force behind regional growth. However this trend was significantly amplified in southern and western France, thanks to residential development surfing on the leisure-oriented concerns of French, British and Dutch people, attracted by an imaginary 'French way of life'. The appeal of sunshine, now supplements that of the seaside, powering development in rural areas, perceived as outdated not long ago, but now idealized. Small towns and large hub-bourgs play a key role in this residential economy and their population dynamic is consequently positive. In the once industrial north-east, the metropolitan dynamic is not strong enough to boost the drawing power of areas in the process of restructuring, with their deep social and territorial scars. The image of these areas in France is currently negative, in keeping with the lifecycle of territories (Lebras and Todd, 2013), following a pattern already familiar in other places, such as the United States (Hoover and Vernon, 1962).

\section{Conclusion}

So what do we mean today when we refer to a small French town? Thanks to a ranking system based on functions and analysis of population dynamics, and more modestly jobs at the urban levels, as defined above, we can suggest an answer to this question.

Small towns in mainland France thus correspond to levels 3 and 4 of our hierarchy. Small towns (level 4) are identified by the presence, at one and the same time, of a high school, large supermarket and hospital with an operating theatre. These are indicators of significant commercial, healthcare and educational functions. The population of these small towns ranges from 6,200 to 35,500 , with 3,500 to 19,000 jobs. To this we may add large hub-bourgs (level 3 ), for which the indicators are the presence of a secondary school, a supermarket and nursing home. This level behaves like a 'very small town', with population ranging from 2,400 and 13,500 , and 1,000 to 4,700 jobs. Level 3 represents the threshold between the urban and the rural spheres of mainland France.

With regard to work, small towns (levels 3 and 4) may be considered as centres of employment in so far as, on average, they offer more jobs than the number of economically active residents. This trend persisted up to the crises of 2008 and 2011.

With regard to demography, our work highlights the reversal of an earlier dynamic. The 1960s saw a positive correlation between population growth and urban hierarchy, in a context of widespread rural exodus. In the 1990s small towns played an active part in this process and consequently benefited from urban dynamics and the increasing importance of the upper 
echelons of the hierarchy. That correlation has now been turned upside down. The migratory balance of cities and medium-sized towns is very often negative now and what population growth they do register is only due to their substantial natural balance. Meanwhile the migratory balance in the countryside is once more positive, even far from towns, due to peri-urban development but also - a feature particularly noticeable in France -due to holiday-making and residential dynamics in the south and west (Figure 4). These trends have consolidated the regional segmentation of the dynamics of small French towns.

Between the productive assets of the city and the residential assets of the countryside, small towns in mainland France straddle the watershed between two territories, two dynamics. This unusual position deserves further study in order to provide a full, balanced response to the complex question of the role of small towns in territorial development (Hinderlink and Titus, 2002), a question of prime importance for local policy-makers.

\section{References}

[1] Aguilera, A. \& Mignot, D. (2004). Urban sprawl, polycentrism and commuting. A comparison of seven French urban areas. Urban Public Economics Review, 1, 93-114.

[2] Bairoch, P. (1985). De Jéricho à Mexico, villes et économie dans I'histoire, Paris: Gallimard.

[3] Baccaïni, B. (2007). Inter-regional migration flows in France over the last fifty years, Population, 62(1), 139-155. DOI: 10.3917/popu.701.0143.

[4] Batty, M. (2006). Hierarchy in cities and city systems (pp. 143-168). In Pumain, D., ed., Hierarchy in natural and social sciences. Dordrecht: Springer, Netherlands. DOI: 10.1007/1-4020-4127-6.

[5] Bell, D. (1976). The coming of the post-industrial society, The Educational Forum, Vol. 40(4), 574-579. DOI: 10. 1080/00131727609336501.

[6] Bergeron, L. \& Roncayolo, M. (1977). La notion de ville en France au début du XIXe siècle, d'après l'enquête de population agglomérée effectuée en 1809-1810, $4^{\mathrm{e}}$ colloque des historiens économistes, Paris.

[7] Berry, B. \& Wheeler, J. (2005). Urban geography in America, 1950-2000: paradigms and personalities, Milton Park: Routledge.

[8] Berry, B. J. \& Garrison, W. L. (1958). The functional bases of the central place hierarchy, Economic Geography, 34(2), 145-154. DOI: 10.2307/142299.

[9] Bordessoule, E. \& Rieutort, L. (1997). Bourgs-centres et pays d'Auvergne (pp. 161-167). Revue de Auvergne. Clermont-Ferrand: CERAMAC.

[10] Chen, A. \& Partridge, M. D. (2013). When are cities engines of growth in China? Spread and backwash effects across the urban hierarchy. Regional Studies, 47(8), 1313-1331.

[11] Christaller, W. (1933). Die zentralen Orte in Süddeutschland, Jena: Fischer.

[12] Cognard, F. (2011). Les migrations résidentielles des Britanniques et des Néerlandais: une figure originale de la nouvelle attractivité des moyennes montagnes françaises, Espaces, Populations, Sociétés, $\mathrm{n}^{\circ} 3$, 509-520. DOI: 10.4000/eps.4672.

[13] Davezie, L. (2012). La crise qui vient: la nouvelle fracture territoriale, Paris: Le Seuil.

[14] Dickinson, R. E. (1967). The city Region in Western Europe, London: Routledge.

[15] Dobis, E., Delgado, M., Florax, R. \& Mulder, P. (2015). Population Growth in American Cities between 1990 and 2010: True Contagion and Urban Hierarchy [conference paper No. ersa15p1128]. Louvain-la-Neuve: European Regional Science Association.

[16] Dubosq, P. (1977). La place des bourgs et des petites villes dans la régulation du procès social (pp. 110-127). In Association des Ruralistes Français, Petites villes et pays dans l'aménagement rural. Paris: CNRS. 
[17] Édouard, J.-C., ed. (2008). Les petites villes françaises entre développement local et métropolisation-mondialisation, Bulletin de l'Association de géographes français 85(1), 3-53.

[18] Faguet, L., Ferrandon, B. \& Jousseaume, V. (2013). L'armature urbaine de la LoireAtlantique, Cahiers Nantais, $\mathrm{n}^{\circ} 1,25-37$.

[19] Fujita, K., ed., (2013). Cities and crisis: new critical urban theory, Newcastle upon Tyne: Sage.

[20] Hall, P. (1995a). The Future of Cities in Western Europe, European Review, 3(2), 161-169. DOI: $10.1017 / \mathrm{S} 1062798700001459$.

[21] Hall, P. (1995b). Towards a General Urban Theory (pp. 3-31). In Brotchie, J., Batty, M., Blakely, E., Hall, P. \& Newton, P., eds., Cities in Competition: Productive and Sustainable Cities for the $21^{\text {st }}$ Century, Melbourne: Longman Australia.

[22] Hilal, M., Piguet, V. \& Schmitt, B. (1995). Communes rurales et petites villes dans la hiérarchie urbaine, Économie et Statistiques, 282, 21-36.

[23] Hinderink, J. \& Titus, M. (2002). Small towns and regional development: Major findings and policy implications from comparative research. Urban studies, 39(3), 379-391. DOI: $10.1080 / 00420980220112748$.

[24] Hoover, E. \& Vernon, R. (1962). Anatomy of a Metropolis. Cambridge, MA: Harvard University Press.

[25] Jousseaume, V. (1996). L'ombre d'une métropole: Les bourgs-centres de la Loire-Atlantique, Rennes: Presses Universitaires de Rennes.

[26] Jousseaume, V. (1997). L'évolution des révélateurs de la centralité rurale (pp. 311-334). In Laborie, J.-P. \& Renard, J. eds., Bourgs et petites villes. Toulouse: Presses universitaires du Mirail.

[27] Jousseaume, V. (2000). La résistance sociale des bourgs et des petites villes: un indicateur de leur résistance économique (pp. 282-293). In Soumagne, J., ed., Les nouveaux espaces ruraux de l'Europe atlantique, Poitiers: Editions de la MSHS.

[28] Julien, P. (2002). Onze fonctions pour qualifier les grandes villes, INSEE Première 840, March 2002.

[29] Kayser, B., Laborie, J.-P., Lugand, J.-C. \& Pechoux, P.-Y. (1972). Les petites villes françaises. Travaux et documents du CIEUToulouse.

[30] Kayser, B., ed. (1993). Les bourgs sur la piste du développement, Paris: Ministère de l'Agriculture et de la Forêt.

[31] Laborie, J.-P. (1979). Les petites villes françaises, Paris: CNRS.

[32] Laborie, J.-P. \& Renard, J., eds. (1997). Bourgs et petites villes, Toulouse: Presses universitaires du Mirail.

[33] Lebras, H. \& Todd, E. (2013). Le mystère français. Paris: Le Seuil.

[34] Lösch, A. (1954). The Economics of Location, New Haven: Yale University Press.

[35] Madoré, F. (2002). L'évolution de l'urbanisation dans l'Ouest français (Bretagne et Pays de la Loire) au cours de la seconde moitié du XX⿳⺈冂大 siècle, Les Cahiers Nantais, n $58,143-157$.

[36] Margetic, C., Bermond, M., Jousseaume, V. \& Marie, M. eds. (2014). Atlas des campagnes de l'Ouest, Rennes: Presses Universitaires de Rennes.

[37] Mellander, C., Florida, R. \& Rentfrow, J. (2011). The creative class, post-industrialism and the happiness of nations, Cambridge Journal of Regions, Economy and Society, 5(1), 31-43. DOI: $10.1093 /$ cjres/rsr006.

[38] Monkkonen, E. H. (1990). America becomes urban: the development of US cities \& towns, 1780-1980, Berkerley: University of California Press. 
[39] Moriconi-Ebrard, F. (1993). L'urbanisation du monde depuis 1950, Paris: Economica.

[40] Oger, B. (1996). Les bourgs-centres de Vendée [unpublished theses]. Université de Nantes.

[41] Piatier, A. (1956). Les attractions commerciales des villes, une nouvelle méthode de mesure. Revue juridique et économique du Sud-Ouest, $\mathrm{n}^{\circ} 4$, pp. 575-602.

[42] Pistre, P. (2013). Les campagnes françaises: un renouveau incontestable mais très inégal, Population \& Avenir, n5, 4-8. DOI: 10.3917/popav.715.0004.

[43] Pumain, D. \& Saint-Julien, Th. (1976). Fonctions et hiérarchies des villes françaises. Étude du contenu des classifications réalisées en France entre 1960 et 1974, Annales de Géographie, 85, 385-440.

[44] Pumain, D. (1982). La dynamique des villes. Paris: Economica.

[45] Pumain, D. (2006). Système de villes et niveaux d'organisation (pp. 236-263). In Bourgine, P. \& Lesne, A., eds., Morphogenèse. Paris: Belin.

[46] Pumain, Th., Paquot, T. \& Kleinschmager, M. (2006). Dictionnaire de la ville et l'urbain, Paris: Anthropos - Economica.

[47] Rochefort, M. (2002). Les notions de réseau urbain et d'armature urbaine, Strates, horssérie, available at http://strates.revues.org/512.

[48] Santamaria, F. (1999). Les villes moyennes françaises: entre hiérarchie et réseaux (étude comparée avec l'Espagne et le Royaume-Uni) [unpublished theses], Lille: Presses universitaires du Septentrion.

[49] Servillo, L. A., Atkinson, R., Russo, A. P., Sýkora, L., Demazière, C. \& Hamdouch, A. (2014). TOWN, small and medium sized towns in their functional territorial context, [ESPON Draft Final Report].

[50] Talandier, M. (2012). L'impact territorial des migrations d'agrément en France (pp. 181-205). In Bourdeau, Ph. \& Martin, N., eds., Post-Tourisme et migrations d'agrément, Paris: L'Harmattan.

[51] Talandier, M. (2013). Redefining the in-place economy and women's role in the local economy of highland areas, Journal of Alpine Research / Revue de géographie alpine, 101(1). DOI: 10.4000/rga.2028.

[52] Talandier, M. \& Jousseaume, V. (2013). Les équipements du quotidien en France: un facteur d'attractivité résidentielle et de développement pour les territoires? Norois 226, 7-23. DOI: $10.4000 /$ norois. 4525 .

[53] Talandier, M., Jousseaume, V. \& Nicot, B.-H. (2016). Two centuries of territorial dynamics: the case of France, Regional studies, Regional science, 3(1), 67-87. DOI: $10.1080 / 21681376.2015 .1090887$.

[54] Zuliani, J.-M. (2002). Les villes moyennes du Grand Sud-Ouest français et les services aux entreprises [Rapport de recherche INTERREG IIC Sud-ouest Européen]. Université Toulouse. 